\title{
COMPARATIVE ANALYSIS OF MENUS IN THE NORTHERN AND SOUTHERN GREAT PLAIN TOURISTIC REGIONS
}

\author{
Dénes Sándor \\ Budapest Business School, College of Commerce, Catering and Tourism 1054. Budapest, Alkotmány u. 9-11.
}

\begin{abstract}
The background of the study is based on previous studies dealing with the areas of Transdanubia and Central Hungary. Those works have proved the hypothesis of author that local ingredients and dishes represent minimum role on menus. The question is how similar or different the choice of menus of Northern and Southern Great Plain is from the previously examined areas of Hungary. Additional questions may also arise in terms of the usage of local ingredients available near catering units.

This piece of work has studied several menus of Northern and Southern Great Plain, Hungary. The material was collected from different types of restaurants, 'csárda'-s and inns. The methodology was two-tier: data collecting on the one hand, and the detailed examination of differences between the catering units on the other hand: the number of dishes, the right order of dishes, the appearance of local ingredients and dishes, the consideration of seasonality, the usage of different cooking methods and group of dishes.

The study reflects the main problems of countryside restaurants in Hungary. Only a minimum number of dishes could be connected to local dishes out of more thousands. All in all, dishes are not as precise and perfect as the 'old ones' used to be; that is why it is important for every expert to keep traditions alive in daily routines and by way of strategic means too.
\end{abstract}

Key words: Northern and Southern Great Plain touristic regions, catering, local ingredients, traditions

\section{Introduction}

The relevance of the topic is given by the global advance in tourism highlighting the choice of dishes offered by catering units. Restaurants, small restaurants (vendéglö in Hungarian) and roadside restaurants (csárda in Hungarian) should preferably offer regional dishes - prepared at least partly from local raw material - in their menu.

The analysis of the studied topic is a current issue since, in accordance with a present hypothesis, one of the problems is that procuring raw materials is much easier and cheaper in hypermarkets. This is the reason why catering companies partly do their shopping in these commercial units and do not spend time on finding local products. Another problem is that local producers cannot always guarantee a constant level of quality and quantity of requested products. Lack of regional dishes appearing in the menu of catering units poses an additional problem.

Bases of the literature background "Appearance of Regional Dishes in the Food Choice of the Southern Transdanubian Touristic Region' (Sándor D., 2008) and 'Analysis of Transdanubian Supply of Dishes - local raw materials, dishes' (Sándor D., 2009) provide proper ground for the present study focusing on the similar characteristics of the Northern and Shouthern Great Plain Touristic Regions. Earlier works covering the Southern Transdanubian region, the entire Transdanubia and the Budapest-Middle-Danube region verified the hypothesis of the Author that local raw materials and regional dishes play an insignificant role in the restaurant menus.

Present study tries to given an answer to the question how the choice of dishes in the hot cuisine catering units of Northern and Southern Great Plain regions differs from that in the previously studied ones. It is also a question whether catering people of the region take advantage of procuring and using locally grown fruits and vegetables. Hungary has gastronomic traditions we should take care of by including authentic local foods and dishes of the region in catering units' menus.

\section{Material studied, area descriptions, methods, techniques}

The study aims to present the menu supply of the Northern and Southern Great Plain Touristic Regions in the years 2005-2008 by a field research of a non-representative sample. The main goal is to survey the choice of dishes and then to evaluate the supply of diverse hot cuisine units restaurants, small restaurants, and roadside restaurants - by professional aspects. Accordingly we may have a view of the quantitative and qualitative parameters of the dishes listed on the menus.

Among others, the analysis covers the logical dish grouping and listing system, the number of dishes, the 
diverse use of raw materials and preparation methods, and the supply of local specialities, traditional foods, creative menu compilations and explanation of ambiguous denominations used in menus.

The analysis of the choice of dishes is based on the menus of 40 restaurants, 10 small restaurants and 22 road restaurants used in the years 2005-2008. Catering units were randomly selected by a non-representative sample of the Northern and Southern Great Plain Touristic Regions. Figure 1 shows the distribution of studied catering units.

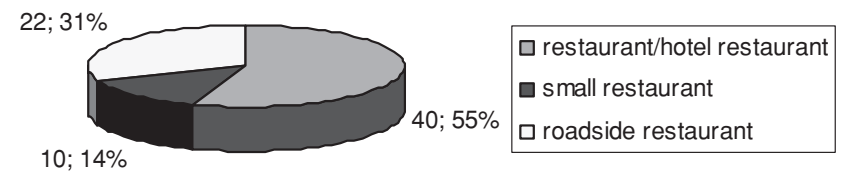

Figure 1. Distribution of studied catering units.

Source: own research

After electronically recording the names and quantity of dishes listed on the menus, meals of certain dish groups were aggregated. Next the average number of meals in each dish group was calculated with handling different types of catering units (restaurants, small restaurants, and roadside restaurants) separately. To provide a more efficient visualization, several diagrams are included to present different distributions and average values.

The average number of cold starters, soups and hot starters by types of catering units can be seen on Figure 2 . In accordance with Hungarian traditions, dishes starting the meal (cold/hot starters and soups) are dominated by Soups.

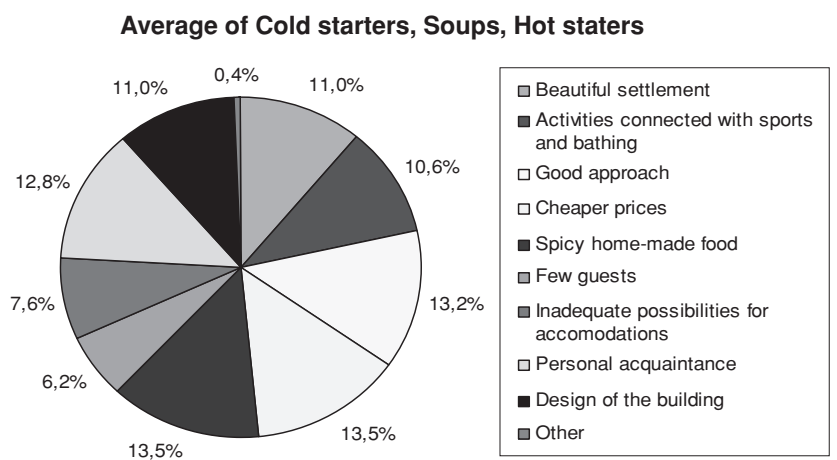

Figure 2. Average number of soups, cold and hot starters in the different hot cuisine units.

Source: own research

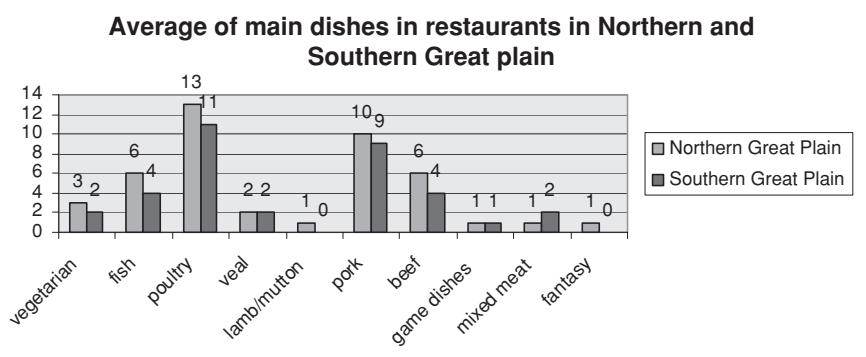

Figure 3. Average number of main dishes in restaurants. Source: own research
Figure 3 shows the average number of main courses in restaurants in the Northern and Southern Great Plain. With regards to main courses in restaurants, the number of poultry dishes is the highest.

Figure 4 presents the average number of main courses in small restaurants in the Northern and Southern Great Plain. In small restaurants the pork dishes are the most popular.

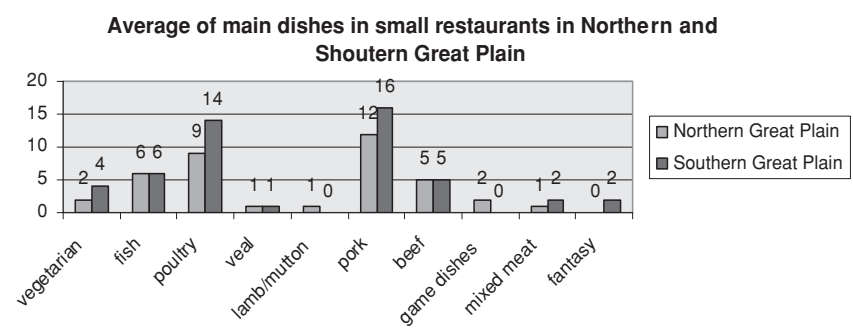

Figure 4. Distribution of main dishes in small restaurants. Source: own research

Figure 5 shows the average number of main courses in roadside restaurants in the Northern and Southern Great Plain. In roadside restaurants the pork dishes are the most popular and in the Northern Great Plain the average number 19 which is extremely high.

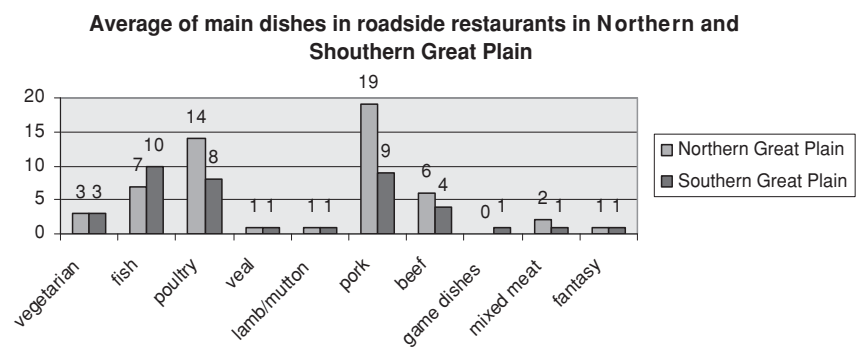

Figure 5. Distribution of main dishes in roadside restaurants. Source: own research

The total amounts of garnishes, Hungarian type of vegetables, salads and sauces (40 restaurants, 10 small restaurants and 22 roadside restaurants) indicate that the average number of different garnishes is 6. (see Figure 6). The average number of Hungarian type of vegetables is 0 in restaurants, small restaurants and roadside restaurants. Average number in case of salads is 7 . In accordance with

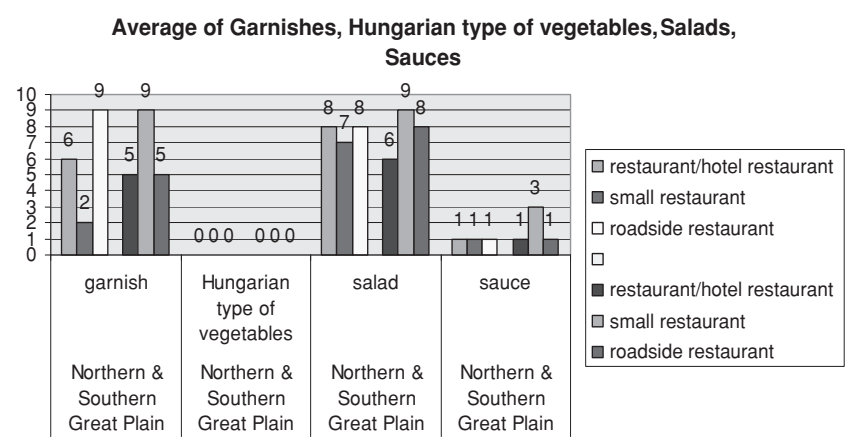

Figure 6. Average number of garnishes, Hungarian type of vegetables, salads and sauces in different hot cuisine catering units.

Source: own research 
Hungarian traditions, offering 6-9 different salads, which includes also pickles, is typical. The average number of sauces is 1 in case of every type of units except small restaurants in Southern Great Plain.

The number of cheese appearing in menus is quite low, namely 1 . The average number of cold desserts is 3 both in restaurants and roadside restaurants, and 2 in small restaurants in Northern Great Plain while 2 in every type of units in Southern Great Plain. This figure is rather low. The average number of warm sweets is 6 . The average number of offered fruits and canned fruits is 1 . These figures are quite meaningful. Concerning the already studied regions, offering 2 kinds of fruits in a restaurant has represented the widest choice so far. How can the customers taste the seasonal tasteful Hungarian fruits?

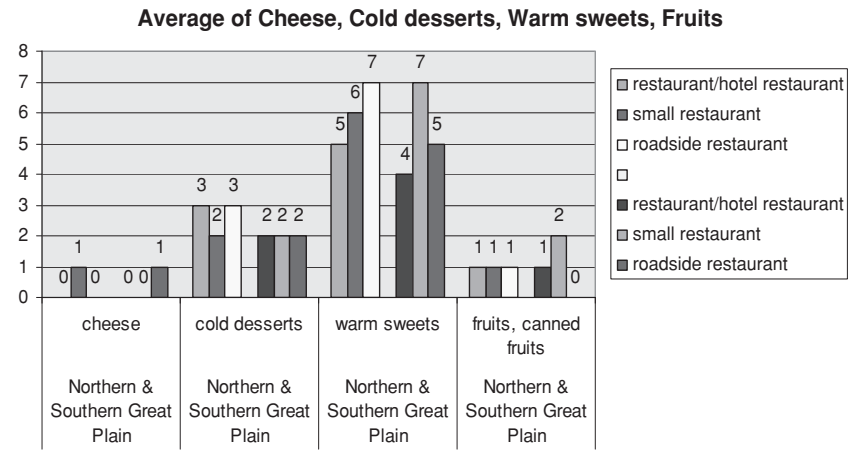

Figure 7. Average number of cheese, cold desserts, warm sweets, fruits and canned fruits in the different hot cuisine units.

Source: own research

\section{Results and discussion}

After processing the data from 72 menus, the primary goal of surveying the choice of dishes in the regions can be summarized as follows: the quality of menus in terms of their content reflects a quite diverse picture.

In some cases, dish groups are listed in menus in an order fashionable some decades ago. As a consequence of this, guests may encounter desserts earlier than main courses or salads.

It is also rather old fashioned to use the categories of readymade dishes and freshly made dishes. Foreign speaking guest may think in this case that the translated denomination of readymade dishes might refer to "meals not cooked at that time". At the same time, several hot cuisine units apply logical listing order of the meals - based on the timeline of consuming.

Fortunately, in Northern Great Plain nearly a hundred dishes prepared of Hungarian raw materials including goose liver, goose cracklings, ewe cheese, ewe curd, salami, sausage, bacon etc. can be found. Regional dishes appear on the menus only at an insignificant frequency. Out of the nearly 3000 dishes surveyed only 100 dishes can be somehow connected to a given region. Often only the denomination of the dish refers to its regional character e.g.: Nyírség Meat Ball Soup, Hen Soup Szatmár Style, Fish Soup of River Tisza, Pancake Hortobágy style, Catfish Tiszalök style, Stuffed Pork rib Szatmár style, Pork rib steak Kunság style etc.

In Southern Great Plain the same number and type of raw materials have been used as in Northern Great Plain. Unfortunately regional dishes appear on the menus only at an insignificant frequency as we could see in Northern Great Plain. Out of the 3000 dishes surveyed only 40 dishes can be somehow connected to a given region. Often only the denomination of the dish refers to its regional character e.g.: kecskeméti kakas rétes-béles, Bean Soup Szénás Style, Betyár Soup of Gyula, Hungarian Great Plain Soup with Dumplings, variations of chicken breast: Szatymaz Style, Maros Style, Félegyháza Style, Great Plain Style, Balástya Style etc.

In accordance with Hungarian traditions, dishes starting the meal (cold/hot starters and soups) are dominated first of all by Soups. With regards to main courses in restaurants, the number of poultry dishes is the highest, while in small restaurants and roadside restaurants the same stands true for pork dishes. Basic supply of vegetarian dish is still one-sided and quite limited (including most of the time only breaded cheese and mushroom).

The range of garnish covers 6 different types on the average, however, the question may arise why catering units don't offer directed main course-garnish pairs? As of international practise, main course is a complete dish including meat (or without meat), garnish and sauce. Fortunately, some of the surveyed menus included no separate garnish category. Strange and surprising, the number of Hungarian type of vegetables is less than minimal, that is zero in all the three types of units (restaurants, small restaurants, roadside restaurants). On the other hand, the average number of salads offered to main courses is 8 . The range of sauces is not too extensive as well, with an average of 1 in almost every catering unit.

The average choice of cheese is 0 ; however, we can find 1 offer in small and roadside restaurants. The standard favourite of cold desserts are ice cream cups, sponge cake Somlo style and chestnut puree. Warm sweets are dominated by pancakes $(60 \%)$ largely contributing to the base of this category. In roadside restaurants, cottage cheese pasta appears in the menu as the most frequent pasta. The choice of fruits, including also canned fruits, is rather narrow, the average figure being 1 in almost all catering units. Why are tasty Hungarian fruits missing from the menu?

There are some places where interesting fantasy names are given to these dishes, e.g.: Mistery of Kocsord, Chicken Breast as Marcsa likes, Hilly Shepherds' food, Women' dream, Favourite of Rózsa Sándor, Favourite of the Roadside Restaurant's Host, Jackals' Favourite.

In many cases there are formal mistakes in the menus, e.g.: the name of the place, the manager name or the name of the chef are missing, the word classification is used instead of categorization which was the terminology on force in the surveyed period, etc. Also spelling mistakes and misuse of terminology often appear in the menus, e.g.: "baconszalon- 
na”, caviar, tuna fish, Gordon blue, beafsteak, etc. The proper use of these terms is as follows: bacon (or "húsos szalonna"). Caviar is the roe of a certain species of fish, namely sturgeon; otherwise it should be named salted roe or salmon caviar in case of salmon. Frozen fillet of sea fish is often referred to as tuna fish but these are generally hake fillets. The proper name of the dish is Cordon Bleu, while it should be spelt as beefsteak in Hungarian menus.

\section{Conclusion}

The following conclusions may be made from the analysis of choice of dishes offered in the menus of 40 restaurants, 10 small restaurants and 22 roadside restaurants in the years 2005-2008:

- A too extensive range of dishes listed in the menu may have an adverse effect on preparing dishes in consistently high quality

- It would be practical to keep selection within reasonable limits at the same time providing outstanding quality dishes for the guests

- Applying international menu formatting experience would be useful

- The terms "Readymade dishes" and "Freshly made dishes" should not be used any more, instead dishes should be included among main courses based on their main raw material

- Range of vegetarian dishes should be extended and made more diverse, and tasty vegetables dishes should be prepared with less or no 'roux' (thickening agent of flour and oil)

- The category of garnishes and sauces is not necessary when garnish and sauce are added to all main courses

- Selection of cheese and fruits should be reasonably widened

- Range of cold desserts should be made more flexible, there should be other desserts in addition to the magic trio of ice cream cup, chestnut puree and sponge cake Somlo Style

- Pancake dominancy of restaurant warm sweets should also be weakened by expanding the choice of this category

- Fantasy dishes cause no problem when an explanation of the dish is added

- Range of regional dishes should be widened, since domestic and foreign tourists are mostly interested in local foods, accordingly it is a shame that out of nearly 6000 dishes only 140 can be attached to the region in any way

- Adding the name of a geographic location to that of the dish does not make the food an authentic local speciality in itself

- It is recommended to include traditional foods in the menus by applying professional literature and the related knowledge of local people

- Using local traditional and regional raw materials is an outstanding possibility for expanding the range of regional dishes. Some of the local traditional and regional raw materials can be seen in Figure 8.

Traditional and regional raw materials, products of the Northern Great Plain Region: Hungarian Grey Cattle, Hortobágy Sheep, Sausage of Debrecen, Plum of Beszterce, Apple of Szabolcs, Cabbage of Hajdúság, Acacia-Honey of Nyírség, Plum pálinka of Szatmár.

In Southern Great Plain Region we can see the following traditional products: goose liver of Orosháza, sausage of Csaba, sausage of Gyula, grey catfish of River Tisza, apricot of Kecskemét, peach of Szatymaz, garlic and onion of Makó, tomato sweet pepper of Szentes

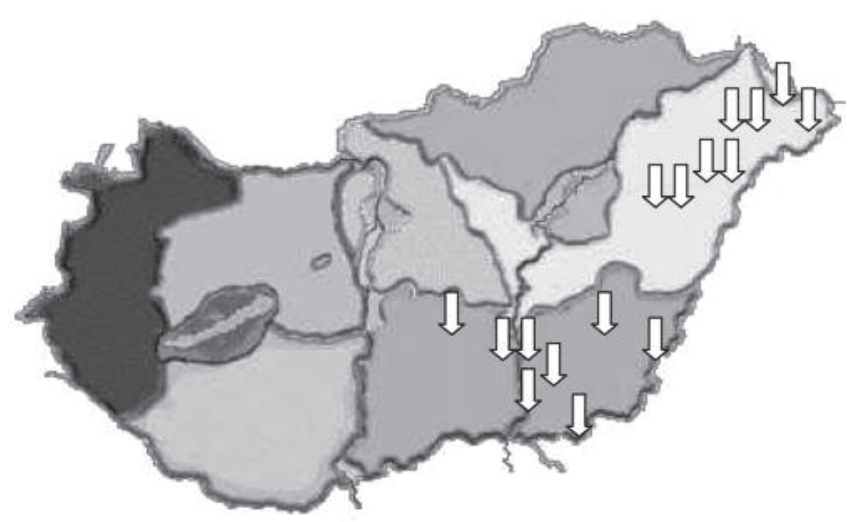

Figure 9. Traditional and regional raw materials and products in the Northern and Southern Great Plain Regions.

Source: http://www.utikonyv.hu/0-release-2/hp-

terkep.php id $=104 \&$ nyelv $=2 \&$ sablon $=360 \&$ tipus $=$ regio $\&$ map $=0 \& x=80000$ $\& y=24600$, Farnadi É. (szerk.) Hagyományok, ízek, régiók, 2002, and own

- A further possibility is to use local wines when preparing the dishes, however, it is not enough to indicate only 'wine' in the menu, it should be detailed e.g.: Venison Stew with paprika flavoured with 2007 Kunsági Zweigelt of Túri Cellar

- Areas to improve the most include the usage of an extremely limited range of raw materials and preparation methods, menu compositions often lacking creativity

- Therefore it would be practical to dismiss the most regular choice of dishes available in almost each and every restaurant and offer regional dishes prepared of local raw materials in the menus

- More attention should be paid to meeting the formal and spelling requirements of the menus

- All in all, current choice of dishes should be updated and a wider range of regional dishes should be offered; the above goals require the cooperation of all professionals in their everyday practise to observe our traditions in the future as well

\section{References}

A. Szigeti (2003): Popular Cuisine Dishes of Transdanubia. Agriculture Publishing Company, Budapest, 2003, 384 p.

D. Sándor (2002): Food Knowledge. Budapest Business School 2002, Budapest, 323 p. 
D. Sándor (2008): Appearance of Regional Dishes in the Food Choice of the Southern Transdanubian Touristic Region. Scientific Yearbook, Budapest Business School 2008, Budapest, pp. 194-208.

D. Sándor (2009): Analysis of Transdanubian Supply of Dishes local raw materials, dishes. College of Szolnok, Economica Scientific Publications, 1/2009, Szolnok, pp. 50-57.

D. Sándor (2009): Appearance of Regional Dishes in the Food Choice of the Southern Transdanubian Touristic Region. Hungarian Tourism Bulletin 1/2009, Budapest, pp. 14-18.

D. Sándor (2009): Local ingredients and regional dishes in the Choice of the Middle Transdanubian Touristic Region. Culinary Journal of Gastronomic and Hotel 2/2009, Budapest, pp. 28-29.
É. Farnadi, (2002, Responsible Editor) Cserhalmi, Zs. - Csoma, Zs. - Némethyné Uzoni, H. - Sipos, B. - Szabó, E. (Editors): Traditions - Flavors - Regions Program. Ministry of Agriculture, Centre of Agro Marketing, Budapest, 365 p.

N. F. Alsószopori (1926): Culinary Cookbook of Transdanubia. Pannon Publishing Company, Szombathely, 1926, 313 p.

Departmental Order: Category Rules of Catering Establishment 43/1998. Budapest. 1998.

http://www.utikonyv.hu/0-release-2/hp-terkep.php?id= $104 \&$ nyelv $=2 \&$ sablon $=360 \&$ tipus $=$ regio $\&$ map $=0 \& x=80000 \& y=2$ $\underline{4600}$ access: January 26th, 2010. 